\title{
Evolutionary Systems Theory: Concepts and Schools in International Relations
}

\author{
Joachim K. Rennstich
}

Summary: As an interdisciplinary approach, evolutionary systems theory borrows from fields such as statistical physics, evolutionary biology as well as economics and others to build on their insights from studies of environments - as systems - and the behavior of actors within those environments — their agency. It provides a bridge between existing and divergent but related strings of research of particular systemic elements as a unifying macro-theory of our social and physical world, fusing multiple approaches into a common model. The unifying key is the focus on the behavior of agents (e.g., individuals; groups; cities; states; world systems) as it relates to the environment (both natural and social) in which these agents act and the feedback between behavior and environment. Evolutionary systems approaches can broadly be placed into two categories: (1) the biobehavioral and (2) the socialevolutionary approach to the study of international relations with the help of evolutionary theory. The point of evolutionary explanations is not to make the case that humans are incapable of making their own choices far from it, learning and selection are critical elements of human agency in evolutionary models. Rather, evolutionary systems theory also includes in its models the structural capacity to make those choices, which derives from and depends on previous choices made, a process also bound by our biological evolution or alternatively by our cognitive limitations and available structural selection mechanisms, regardless of the relative complexity of human learning capacity.

Keywords: evolutionary models, systems theory, complexity, IPE, world system, innovation, development 


\section{Evolutionary Approaches and the Study of our World}

Systems of interaction matter: for the outcome of these interactions, as well as for the behavior of the interacting agents, both in the physical and the social world. Agents act according to rules, which are captured in social systems of interaction. These social interaction systems, in turn, shape the underlying rules of individual agency. Expressed differently, they enable and limit the set of choices actors have available to act upon.

But systems of interaction are not handed down a priori to social agents; only their boundaries are. The development of such systems is the result of a variety of factors, ranging from biological issues such as disease or cognitive capacity, to geological considerations and social technologies. One of the main contributions of the world systems literature (with or without the hyphen) to the study of international relations has been to uncover the development and interaction of these systems on multiple levels: never in isolation, but rather as part of a larger whole. As importantly, world systems analysis has been able to raise awareness of the need to study both the kind of "worlds" we live and interact in, as well as those factors that help shape those worlds. The fight in the international relations literature over the dominance of agency or structure is therefore beside the point: both matter and are dependent on one another. Agency breeds structure, but structure also breeds agency.

Evolutionary systems approaches, especially in combination with complex systems theory, have proven to be a very effective means to study agency and structure in tandem. As an interdisciplinary approach, they borrow from fields such as statistical physics, evolutionary biology, and economics, and build on their various insights regarding environments as systems, and the agency of actors within those environments. This is particularly useful for students of globalization. While liberal and realist approaches provide insights into individual parts of the 
globalization process, they lack a comprehensive, multilayered view of the entire world system. Whereas liberals will focus mostly on group actors such as multinational corporations, and other non-governmental and intergovernmental organizations as primary actors of transformative change - or lack thereof — realists will center their analysis of globalization around states as the core actors, just as Marxist and post-Marxist approaches will favor an analysis primarily based on class analysis and the unequal structure of the world system.

The frustration with these limitations has led a growing number of scholars to look outside paradigmatic fences, not just to neighboring schools of thought in the international relations literature, but also outside of the field of political science, to sociology, economics, anthropology, mathematics, and biology. Here we present first the core concepts and terminological clarifications underlying evolutionary theory, followed by a brief introduction to some of the existing approaches more commonly represented in the international relations literature, and lastly address some of the criticisms aimed at evolutionary systems approaches.

\section{Evolutionary Theory - Concepts and Terminology}

Evolutionary theory, understood as a theory and methodology to study the process of change among living forms, is associated mostly with the scientific field of biology. The original formulation of evolutionary theory by Charles Darwin and Alfred Russel Wallace, along with work by Jean-Baptiste Lamarck and others, dealt with the genetic evolution of the origin and adaptation of species (Bowler, 2003; wider applications in Nowak, 2006; also Nowak \& Coakley, 2013). Modern evolutionary theory in biology is still largely based on five theories that make up the core of Darwinism (Mayr, 2001; Gould, 2002; also Thayer, 2004): 
(1) evolution: the world is neither constant nor perpetually cycling, and organisms are transformed steadily over time in a non-directive manner;

(2) the common descent of life: every group of organisms descends from ancestral species;

(3) the gradualness of evolution: evolution as a whole proceeds relatively slowly and gradually, rather than in jumps;

(4) the multiplication of species: great diversity of life is expected; and

(5) natural selection: evolution proceeds by means of variation, differential reproduction, and heredity.

Modern evolutionary theory serves not only as the intellectual foundation of evolutionary biology but also of evolutionary systems theory in international relations (e.g., Somit \& Peterson, 1992, 2003). Especially students of large-scale and long-term human social and political development have long been attracted to this approach. Evolutionary theory is a powerful tool that helps to explain the process of change of living organisms - the dynamics of change and why and how this change occurs. As such, it provides a cohesive framework that can also be applied to study of the interaction of individuals with their social and natural environments at all levels of analysis (Bowles \& Gintis, 2013; Cronk \& Leech, 2013).

The main elements of any serious theory of evolutionary dynamics in the social sciences resemble the elements of biology: reproduction, mutation, selection, random/genetic drift, and spatial movement; although differences exist in terms of their specification. The idea of variation as well as a focus on larger macro-structures, for example the so-called international system, is widely acknowledged and present in mainstream approaches of international relations. What constitutes reproduction and mutation or selection, however, is not immediately clear in the context of the study of world politics (Plotkin, 1988; Campbell, Brewer \& Collins. 1981; Mayr, 
2001). It might therefore be more helpful to focus instead on the following uses of the terms "unit," "environment," and "selection":

1. A unit (e.g., individuals; groups; cities; states; world systems) or set of units develop innovations (i.e., mutations) and store their results (i.e., reproduction).

2. A changeable and changing environment, both natural and social, to which the unit or set of units responds. This is important for the aspects of random/genetic drift and spatial movement.

3. A set of selection mechanisms, both relating unit to environment and transmitting traces to the unit's successors, corresponding to the concept of selection.

Whereas the concept of units and the importance of environments are present in all major paradigmatic international relations frameworks, the particular importance of "selection" as a core concept of evolutionary theory warrants a more thorough discussion here.

\section{Natural Selection}

Natural selection has been conceptually refined in two ways since Darwin's initial proposition, in that (a) natural selection at the level of the genotype - the total genetic constitution of an organism or population, the whole repertoire of the variant paths of development that may occur in a specific group in all environments, favorable and unfavorable, natural and artificial affects the phenotype - a biological system constructed by successive interactions of the individual's genotype - capturing the totality of characteristics of an individual or population (Campbell, 1974a, p. 36), and (b) that natural selection is a two-step process from the production 
of genetically differing individuals to the equally important step of the survival and relative reproductive success of these individuals (Hull, 1988).

The idea of using a theoretical concept dominant in biology for the study of social or cultural phenomena has yielded a strong response from a number of critics (Lewontin, 2003 Lewontin, Rose, \& Kamin, 1984; Wallerstein, 1995). We should therefore make it very clear, what evolutionary systems theory is not.

First and foremost, evolutionary systems theory as discussed here is not an argument for a sociobiological view in a narrow genetic sense; in other words, it is not an argument about the triumph of nature over nurture — a false dichotomy at any rate (see Thayer, 2004, especially footnote 1). Especially with the introduction of sociobiology in the mid-1970s as an attempt to synthesize the biological and social sciences as tools to study human behavior (Wilson, 1975, 1978), evolutionary explanations of social and cultural behavior have often been identified with genetic determinism (Gould, 1981; Lewontin, 2003). Even though a reductionist school does indeed exist, this is an unfortunate misconception of evolutionary theory not just in the social sciences, but also in biology, that Charles Darwin himself already had to struggle with (Darwin 1872, pp. 395f).

It is important to remember, that all evolutionary systems approaches present in the social sciences emphasize the need to study the population as the fundamental basis of any evolution: individuals, genes, or ideas can change over time, but only populations evolve (Nowak, 2006; cf. Sanderson, 1990), and do so in a long-term fashion. Differences, of course, exist over what constitutes "long” or “term” (Chase-Dunn \& Hall, 1997; Denemark, Friedman, Gills, \& Modelski, 2000; see especially Frank \& Gills, 1993). The more recent inclusion of complexity theory into the toolkit of evolutionary systems theory (Dark, 1998; Devezas \& Modelski, 2003; 
Gintis, Doebeli, \& Flack, 2012; Rennstich, 2008; Teisman, Buuren, \& Gerrits, 2009; Wright, 2007) allows the integration of biological evolution and social or cultural evolution as part of a larger system, conceptualized as a complex system, and provides an important addition to the field.

The following section introduces some of the main evolutionary systems approaches present in the international relations literature. We have excluded here approaches that use only parts of the above described paradigmatic frame, such as liberal approaches with their special focus on individual and group actors and their ability to shape a social environment. The importance of group culture as a behavioral influence, not only for humans but in nature at large, has been widely acknowledged in the general evolutionary literature (Bonner, 1980), and especially in the research on human ethology (see e.g., Boyd \& Richerson, 1985; Csányi, 1989; Durham, 1991). We furthermore exclude approaches that might use the term "evolutionary" in their title or description of approach, but do not base their analysis on the epistemological toolkit of evolutionary theory. These analyses often focus on a particular sequential historical development in the hope of identifying some pattern, but do not use any specifically evolutionary analytics.

\section{Evolutionary Systems Approaches in International Relations}

Evolutionary systems approaches in the social sciences trace their origins back to the beginning of evolutionary theory in the nineteenth century. With the advancements made in evolutionary theories since their initial proposition in biology, a number of authors have also forwarded the 
idea of an evolutionary paradigm for world politics following earlier attempts in the French Annales and world-system literatures (Chase-Dunn \& Hall, 1997; Hall, 1999; Wallerstein, 1974).

Evolutionary systems theory as it pertains to international relations can broadly be placed into two categories: (1) the biobehavioral; and (2) the social evolutionary. The former believes the foundations of human behavior allow, or even force us to employ evolutionary theory to study social systems (e.g., Campbell, 1974b; Falger, 1994; Johnson, 2011; Reynolds, Falger, \& Vine, 1986; Sanderson, 2001; Somit \& Peterson, 2003; Thayer, 2004). The latter favors the use of evolutionary theory based on the analogous developmental pattern of social systems to those found in the natural world (e.g., Modelski, 1990, 2000; Spruyt, 1994).

Plotkin (1994), makes a compelling case for the use of evolutionary models based on biological concepts in the study of social behavior, focusing on the role of adaptations as crucial determinants of whether organisms (human or otherwise) survive and reproduce or not. Human beings in this view are a "finely woven cloth of adaptations," whereas adaptions are macrofeatures of the organization of living things that are formed by a very long process of interaction between the environment and successions of organisms that make up lineages of organisms extending over long periods of time (Plotkin, 1994, p. xiv). Whether or not humans are a special case is not critical in this perspective, since

[the] human capacity to gain and impart knowledge is itself an adaptation, or a set of adaptations. ... We simply will not understand human rationality and intelligence, or human communication and culture, until we understand how these seemingly unnatural attributes are deeply rooted in human biology. They are ... the special adaptations that make us special. (Plotkin, 1994, xiv) 
Proponents of the analogous use of evolutionary theory for the study of social systems argue that biological and social systems are both subject to evolutionary processes and for that reason share certain similarities: they are complex systems that exhibit selection pressures, cooperative and synergistic features; and in their transformations they employ information and thrive on innovation. Physical and biological nature, social as well as cultural, cannot be simply equated with each other, because their processes differ substantially, but they do share general properties that allow for the careful application of the same language, and the employment of analogous concepts (Modelski \& Poznanski, 1996). Here we will focus on the general application of evolutionary theory as a tool that pertains to the study of world politics rather than on deeper epistemological debates. For a discussion of the difference in these two approaches and whether they actually matter in terms of how evolutionary theory is used, see for example the first two chapters of Thompson (2001) or the discussion documented in Niedenzu, Meleghy, \& Meyer (2015).

Miles Kahler (1999), and George Modelski and his collaborators (Devezas \& Modelski, 2003; Modelski, 1990, 1996, 2000, 2001; Modelski \& Poznanski, 1996; Modelski \& Thompson, 1996) published some of the earliest explicitly evolutionary work in the contemporary International Relations literature. Modelski and Poznanski were also instrumental in pushing this approach onto the international relations scene in the publication of their special issue of International Studies Quarterly that features articles by Farkas (1996), Florini (1996), Hodgson (1996), and Gilpin (1996). William R. Thompson (2001) edited a volume that continued this path and brought together a wider range of approaches and authors, connecting evolutionary theories to other, more dominant approaches in IR, as well as applying evolutionary approaches to the study of conflict, cooperation, and international political economy. Rennstich (2008) has continued to 
advance this framework, conceptualizing world system evolution as a complex system. Examples of studies in international relations that focus on the dynamics of evolutionary processes based on the concept of punctuated equilibrium include Somit \& Peterson (1992) and Diehl \& Goertz (2000). Within IR, scholars both within and more loosely associated with the world system perspective have been most active in the use of evolutionary analysis (e.g., Turchin, 2016; Rennstich, 2008; Modelski, Devezas \& Thompson, 2008; Wallerstein, 1995). Outside of political science and international relations, this framework continues to cause increasing interest in the social sciences (Niedenzu et al., 2015) or related fields (e.g., Kradin, 2015).

\section{Core Features}

Just as in biology, evolutionary systems theory in international relations provides a bridge between divergent but related strings of research of particular systemic elements. It serves as a unifying macro-theory of our social — and in some applications also physical — world, fusing multiple approaches into a common model. These approaches have different foci of inquiry and may be rooted in different scientific traditions. They aim to combine the insights garnered from evolutionary economics, illustrating the problems of competition, innovation, and technological change, with findings from evolutionary psychologists and their inquiries into cognitive decision-making processes, and the epistemological insights into scientific progress as steered by repeated trials and error-elimination procedures. The unifying key is the focus on the behavior of agents as it relates to the environment in which these agents act, and the feedback between behavior and environment. 
To be sure, other international relations approaches do the same, but few of them do so in such a comprehensive and explicit fashion. An evolutionary paradigm does not limit itself to a focus on a certain set of actors or level of analysis, as is often the case in IR approaches, but allows a flexibility that enables students to focus on various levels, micro and macro, and multiple actors simultaneously. It also has a strong temporal element that allows the identification of dynamic processes rather than — as other international relations approaches are often prone to assuming a linear or static relationship either between actors, actors and environments, or the environments themselves. From an evolutionary viewpoint, the answer to questions of human progression lies in the feedback between ecologies and actors: as environments and actors change, so too do the probabilities that some approaches will survive or prove more successful than others, while others will wither or even disappear.

As discussed earlier, of interest is not simply change in itself, but rather the interaction between changing elements. For example, at a certain point in time, a number of technologies might exist as a result of economic innovation or variations among states. At a subsequent time, some of these variations might have vanished or declined in importance relative to others For example, electrification crowded out other forms of energy use, such as steam, in the early twentieth century. Thus, the crucial question is why one approach has been favored - or in evolutionary terms "selected" - over others. Change is a constant phenomenon rather than a disruption from the norm. Far from searching for some forms of equilibria, evolutionary frameworks aim to identify and understand the dynamics of the system and its subsystems.

It is important to remember the underlying argument, that change in this context is neither linear and constant, nor completely random. Change appears in a variety of shapes and sizes. Whereas some changes can have large, immediate effects, other changes develop their impact gradually 
and more incrementally. These interactions and feedback effects have an important impact on the timing of change. Often a number of previously insignificant and incremental changes can suddenly grow in importance and diffuse throughout the system when paired with new innovations.

For example, over the course of history we repeatedly see inventions occurring relatively unnoticed and remaining apparently insignificant. They only gain in significance if and when placed in an appropriate socioeconomic environment. This dynamic has been explored in great depth as part of the punctuated equilibria literature (Diehl \& Goertz, 2000; Eldredge, 1985; Eldredge \& Gould, 1972; Somit \& Peterson, 1992). What becomes crucial from an evolutionary perspective is to uncover the pattern of change within the system of interest, for example the development of world systems or the occurrence of large-scale conflict.

\section{Units and Population}

Similar to Dark (1998), Modelski and his collaborators (Devezas \& Modelski, 2003; Modelski, 1990, 1996, 2001; Modelski \& Thompson, 1996) suggest the need to view an evolutionary world politics program as a 'human species approach', with the individual as the ultimate arbiter and level of analysis, and with world politics as a process of organization and reorganization of the human species as a whole. In this view, global politics promotes the evolution of new forms of political and social organization, manifested in institutions in a broader sense. For Modelski, as a proponent of a non-biobehavioral evolutionary approach, neither nations nor national societies evolve. What evolves are policies, strategies, and institutions that provide coping mechanisms to a changing environment. In other words, rather than viewing units such as nation states or 
societies as relatively fixed units with established interaction patterns and processes, Modelski and also Dark argue instead for the need to focus on the agency-space or -capacity that evolves out of the interaction between individuals and in the formation of collectives, from small groups to global networks. The focus here lies on the interaction-processes between the various subsystems rather than on assumed behavioral features of certain actors.

Similarly, the world-systems schools (with and without a hyphen, as per Wallerstein, 1993) provide a rich literature on comparisons between "worlds" as units of a larger macro-structure (Hall, 2017; Hopkins \& Wallerstein, 1980; for a general overview, see Shannon, 1989). A world system, in this view, is conceived of as the social organization of the human species, viewed as one population. This population exists in either an organized or unorganized state, united by basic institutions such as cities, writing, states or state systems, technologies, or intersubsystem networks such as trading networks. This notion of the world system (or meta world system) is similar to the ones proposed by other authors basing their analysis on an evolutionary world system framework (Denemark et al., 2000 and Thompson 2001 provide the best overviews of the various evolutionary world systems approaches). It also comprises the basis of the development of the world system as a complex system. However, even among those related through a general world systems perspective, there exists a wide range of opinion regarding the composition of its population, system identity, the level and existence of interaction between its subsystems, and its evolutionary development amongst other issues of content. Broadly speaking, those divergent views can be grouped into two perspectives: (1) the singular and (2) the pluralist system perspective.

The singular perspective is based on the concept of a Kantian universal history of mankind and relies to a large degree on the writings of William McNeill (McNeill \& McNeill, 2003; McNeill, 
1982, 1991, 1999) and other proponents of a world history (Pomper, Elphick, \& Vann, 1995, see e.g., 1998) or Big History (Aunger, 2007; Christian, 2011; Pomper et al., 1998; Spier, 2010) approach. McNeill argues that the various human cultures have experienced significant degrees of interaction at every stage of their history — and never more so than during great transformations of the world system over the long period of its evolution. This view contrasts with a pluralistic perspective, positing multiple separate civilizations pursuing essentially independent careers (Huntington et al., 2013; Toynbee, 1934). Such a species concept implies interdependence among its members given a close common origin.

Thus, while linkages constitute important elements of the world system, their mere existence (i.e., trade networks, flows of communication or technology, migration, etc.) cannot be the central focus of an evolutionary framework. In order to demonstrate the existence of a single world system, however, we need to be able to identify institutions that potentially or actually have species-wide impact and significance. In other words, we need to focus our attention on both agency and structure in such a world system.

\section{Agency as Evolutionary Drive}

Evolutionary systems theory also takes into account the role of agents as it acknowledges that social change is driven by innovations related to individual choices. A general evolutionary systems framework for the social sciences that focuses on the development of a global system, especially one that views it as a global complex system, will always be based on a common evolutionary logic that explains the creation of possibility space, or in other words the potential options for change open to the systems and its parts (Clark, Perez-Trejo, \& Allen, 1995). This 
evolutionary logic driving the global system process is based on the following set of epistemological assumptions, borrowed here from evolutionary economics, concerning agents and their agency (Andersen, 1994, p. 15):

- agents - e.g., individuals, groups, organizations, etc. — can never be perfectly informed and thus have to optimize at best locally, rather than globally;

- an agent's decision-making is generally bound to rules, norms, and institutions;

- agents are to some extent able to imitate the rules of other agents (imitation), to learn for themselves, and are able to create novelty (innovation);

- the processes of imitation and innovation are characterized by significant degrees of cumulativeness and path-dependency, but may interrupted by occasional discontinuities;

- the interactions between agents take place in situations of disequilibria and result in either successes or failures of commodity variants and method variants as well as of agents; and finally

- these processes of change are non-deterministic, open-ended, and irreversible.

As pointed out earlier, change is necessarily at the heart of any evolutionary model. However, given the scope of the analysis in terms of levels of analysis, temporal and geographical orientation, as well as areas of inquires, it is impossible to focus on all effective processes with equal weight. Yet, what particular changes, or structures of change, are most important? Any generalization must be simplifying. Thus, the main goal of an evolutionary model must be to unravel the main change processes that drive the system and provide a point of reference over a multitude of levels of analysis and areas of inquiry. The concept of long-cycles of global politics driving global political evolution (Barnett, 1998; Goldstein, 1988; Modelski, 1987; Modelski \& Thompson, 1996; Rennstich, 2008) and in particular the dynamics of so-called K-waves (see 
section Evolutionary Economics) are prime examples of such innovation-agency and its effect on structural change as part of an evolutionary model.

\section{Mutation (Innovation and Variation), Selection (Imitation, Adaptation), Diffusion and Fitness}

An evolutionary systems framework that analyzes structural change at a large or even global scope must focus on two principal levels of structure:

(1) major institutional change, e.g., the rise of the market economy, and;

(2) organizational change, e.g., the emergence of global organizations in tandem with the nation-state.

In addition, some approaches highlight the process of nested sequences of separate but connected evolutionary processes with their own, and differing yet synchronized dynamics (see Modelski \& Thompson, 1996; Rennstich, 2008). These changes constitute adaptations based on mutation, that is, social and physical innovations. Some of those mutations, in turn, are consequently "selected" through mechanisms of adaptation based on imitation by other agents. The process of population-wide imitation diffuses these innovations/mutations through the system as a whole, which in turn results in population-wide adaptation (e.g., Ziman, 2000). This sequence constitutes "selection" in the evolutionary sense (Forber, 2009).

The process of imitation is better understood as learning in the context of social evolution, drawing on behavioral and cognitive biological theory (Langer \& Killen, 1998; Wilson \& Sober, 1994). Population-wide adaptation in this sense is a concept usually referred to in the social sciences as institutionalization (for an example of this approach, see Baum \& Oliver, 1996). One 
critical component in this process of order-structuring are generational cohorts as a key subsystem of collective learning, which includes not only the capacity for adaptation, but also for innovation (Nowak, 2006; Plotkin, 1994).

\section{Buddenbrook Cycle - An Example}

A good example of this kind of learning is the process of the establishment of new leading economic sectors as part of a larger world system evolution, illustrated graphically in Figure 1. Based on innovations originating in new forms of socio-technological behavior of a first generation of innovators, the following second generation groomed in this new environment transforms these innovations into a coherent socio-technological paradigm, actively forming the predominant leading sectors of this first part of an evolving long-cycle and establishing themselves as a "lead-group" that other imitate or copy.

\section{[insert Figure 1 about here]}

The lead-group third generation, while still enjoying the spoils of the high returns on the leadership based on this socio-technological paradigm — now dominating socio-economic norms and rules of engagement and largely adopted by others - remains "stuck" in it, unable to adapt to emerging new alternative socio-technological innovations being developed by "outgroups" which are tied to and part of the leading system, but on the periphery of the lead-group. As a result, the lead-group allows new socio-economic innovations in alternative and geographically separate clusters to pass them by. Rather than adopting the dominating, yet

already relatively declining institutionalized socio-technological patterns largely controlled by representatives of the third generation of the still-dominating lead-group, a newly emerging out- 
group generation builds on the innovations and possibilities of the previous leading-sector innovations, developing the carrier technologies to establish a fresh set of leading sectors utilizing this technological infrastructure (see e.g., Hall \& Preston, 1988). In doing so, they become a new "first generation" of innovators and the above described cycle emerges anew, albeit now clustered in the former out-group and usually also in a geographically separate location.

This leaves the fourth generation to witness the rise of challengers to the established order and eventually the emergence of a new socio-technological paradigm often outside of its domain of control. Sociopolitical and economic change seen in this light is always a historical, dynamic process involving the use as well as the creation of resources (as diverse as simple objects, techniques and knowledge, or even entire social organizations).

\section{Social Learning and Self-Organization}

It is important to note that this evolutionary logic is driven in large part by human agency. However, this agency takes place and is embedded in a social and technological context. In other words, whereas the driving logic — the need for optimization of tasks as part of human agency — of this process remains the same, its context changes, constituting a social learning algorithm of evolutionary change that is at work at all levels of the global system, from the individual to the global system as a whole.

This process can be understood as self-organization, a feature of emerging order without an external (or internal) orderer. The arguments developed here rest on the assumption that thinking of the global system as a complex, self-organizing social system allows us to step outside the 
constraints of the study of the institutions and processes that help shape the development of a single global system (see for example Sassen, 2006; Sawyer, 2005) and instead enables us to analyze the underlying logic that drives, curtails, and reinforces these processes. Evolutionary approaches now also offer frameworks that combine complex system analysis with evolutionary theories of global system development.

\section{Complexity — Social Structures as Complex Systems}

The evolution of social structures, understood as complex systems that form larger world system developmental processes, have been of interest to students of international relations since Axeldrod's early work on cognitive mind-maps (Axelrod, 1976), and further developed in his seminal work on the evolution of cooperative strategies (Axelrod, 1984, 1997). A growing literature in the past two decades yields a substantial body of work that can be employed in other evolutionary system approaches. Complex systems analysis offers insights into the way systems establish order without a singular or initial ordering entity. Order — or developmental logic — in such systems emerges based on feedback resulting from trial and error, adaptation, and systemwide learning, resulting in a system that features self-organization (Allen, Clark, \& Perez-Trejo, 1992; Axelrod, 1997; Beinhocker, 2006; Dopfer, 2005a; Devezas \& Corredine 2002; Harrison, 2006; Jervis, 1997; Klüver, 2000; Mainzer, 2007; Miller \& Page, 2007; Mitleton-Kelly, 2003; Rennstich, 2008; Ziman 2000, cf. see Shaw 2000).

The formation of a world system understood as a long-term social system (involving economic, political, and cultural processes) resembles such an emerging ordered system that lacks a single orderer. No single power, whether an empire, state, or any other unit, has transformed the human 
social world over the last five hundred or thousand years (or any other period) into the world we experience it the beginning of the 21 st century. Rather, globalization has been the result of a number of reoccurring processes of trial and error, adaptation, and system-wide learning, and emerges as a complex system based on the principle of self-organization. Employing the general lessons derived from the study of complex systems, it is possible to identify the general or meta developmental logic of long-term globalization processes while at the same time leaving room for divergent schools on the factors that influence important order-structuring elements such as learning or adaptation in the system.

All socio-political forms ultimately derive from human agency. This requires special attention to the link between agents, structure, and the system as a process. That link is constituted by decision-making, whether constrained or freely made. However, with increased socio-political complexity comes greater need to manage information. This, so Dark (1998, pp. 121-122) explains, leads to the following internal dynamic: complex socio-political systems will necessarily increase in complexity, with the consequence of a higher rate of decision-making.

As a result, the need for more efficient information processing increases in order to respond to decision-making requirements produced by complexity and the structures it employs (Hodgson \& Knudsen, 2007). This complexity dynamic not only increases at first the opportunity for sociopolitical innovation to occur, but also the potential for instability. As the complexity of the system increases, the range of possible decisions promoting further growth will decrease, and an increasingly complex system will become progressively path-dependent and lose its adaptive flexibility.

Unhindered hyper-coherent option-narrowing will eventually precipitate collapse, which will be a sudden occurrence. Socio-political complexity will rise to the edge of chaos — understood as 
an unordered, non-repeating system constellation. The relationship between innovation and systemic development is based on information processing and decision-making, and prompted by interaction, generating a successional model of endogenous socio-political change where the successor system might follow a similar trajectory to that of the system which it replaces, collapsing itself in time and being replaced by another emerging socio-political system. Progression takes place stochastically through trial and error, and random non-average fluctuations (see Devezas, 2005).

In this process, the system self-organizes and 'learns' to configure and reconfigure itself toward increasing efficiency, and in this manner with each iteration it performs some activity better. Each stage corresponds to a given structure that encompasses previous self-organization, learning, and current limitations (Devezas \& Corredine, 2001, p. 22). As pointed out earlier, decision-making (and thus the process of agency) does not take place in an isolated environment but rather a strongly contextual one. Agency affects the environment in which it unfolds, but also is formed by it. Thus, it is important not only to focus on the agents on a multitude of levels, but also to identify the contextual environment in which this agency takes place.

Change in complex systems, whether in the direction of greater or lesser complexity, produces a trajectory or historical path, limiting future options and thus becoming path-dependent. As a consequence, complex systems like the nested global economic, political, social, and cultural processes that form the world system we identify, exhibit a tendency to self-organization that is the endogenous ordering into hierarchies that provide them a system-wide form. Thus, these complex systems exhibit morphogenesis - i.e., the development of an organism or of some part of one, as it changes as a species — based on processes that are partly independent of agency, although they require agents to both initiate them and enact them. The way the interrelationships 
between parts of the systems are established thus becomes crucial for our understanding of the dynamics of these coevolving structures.

\section{Related Evolutionary Approaches}

Evolutionary frameworks outside of the natural sciences have found homes in sociology, political science, and economics, and historically also anthropology and archaeology. They have emerged as powerful tools to study complex social processes involving a wide array of factors, such as geography, technology, institutions, commercial developments, financial flows, warfare, etc.

In political science, evolutionary theories have become particularly influential for the work of scholars devoted to the study of the international political economy as a way to overcome the limitations of institutional approaches. The contributions to evolutionary systems theory from sociology are hard to separate from those of political science. Other related fields have also contributed to evolutionary systems theory as applied in the social sciences, for example in archaeology (Maschner, 1996; O’Brien, 1996; O’Brien \& Lyman, 2000; Teltser, 1995) or anthropology (Boyd \& Richerson, 1985; Durham, 1991; Kosse, 1994; White, 1959). In this section the main focus will be laid on the contributions of evolutionary economics, followed by a shorter discussion of the Social Structures of Accumulation and the French Regulationist school. 


\section{Evolutionary Economics}

From the beginning, a unifying characteristic of evolutionary economics has been its criticism of neo-classical liberal economic theory. To counter neo-classical liberal assumptions, evolutionary economists have been developing an alternative theoretical foundation with which to analyze economies and economic change (Andersen, 1994; Hidalgo, 2015; Hodgson, 1993; Saviotti \& Metcalfe, 1991; Witt, 1991) as well as economic policy making (Dopfer, 2005a; Fornahl, Henn, \& Menzel, 2010). In the tradition of Schumpeter (1912), the work of Nelson and Winter (1974, 1982, 2002) and others (Dopfer, 2012; Hodgson, 1993, 2004) challenged the static framework of liberal economics and proposed an evolutionary framework instead (Beinhocker, 2006; Dopfer, 2005b). In contrast to the liberal foci on allocation and equilibria, evolutionary economists postulate that economic activities involve continuous disequilibria and dynamic processes of change, involving the creation of new resources. The ultimate outcome of this change remains unpredictable in advance. The major focus of theory must therefore be on the process of change. Here we focus on the long-wave tradition of long-term change and only point the interested reader to other related evolutionary frameworks on economic change, combining ecological, anthropological, sociological, historical, and economic analyses such as the work of North (1981); Pomeranz (2000); and Jones (1988/2000).

The well-known work by Polanyi (1944; Polanyi, Arensberg, \& Pearson, 1957), who developed a three-stage evolutionary model of economic growth, and Schumpeter (Andersen, 1994; Schumpeter, 1954/1996), have laid the foundation of most long-term evolutionary models that involve economic elements. Schumpeter aimed to bridge theoretically and methodologically existing statistical approaches, applying the concept of Kondratiev waves, and historical approaches, combining them both in a long-wave approach. Kondratiev's decisive contribution 
for which he laid the theoretical groundwork in his publications in the 1920s was the presentation of the hypothesis of long-waves in capitalist development, referred to as Kondratieff- or K-waves (see Kondratieff and Stolper, 1935; Makasheva, Samuels, \& Barnett, 1998).

For some time, these K-waves represented an important topic in economic research and ironically has seen a regular rise and decline in interest ever since (Berry, 1991; Duijn, 1983; Freeman \& Louçã, 2001; Goldstein, 1988). The growth of mechanistic theories and models, propelled by new statistical opportunities, reduced concerns about an evolutionary development of capitalism. A revival of the program occurred nonetheless. The neo-Schumpeterian approach put forward by Rostow (1952) features quite prominently in political science, particularly so in the early development literature. In the 1980s, the research on long-waves gathered momentum again (Kleinknecht, Mandel, \& Wallerstein, 1992; Modelski, 1987; Reijnders, 1997; Vasko, 1987).

Frameworks for the analysis of sociopolitical systems reflected in the international political economy literature include Dosi's technological concept (Dosi, 1984; Dosi, Freeman, Nelson, Silverberg, \& Soete, 1988), and Freeman's concept of techno-economic paradigm (Freeman \& Perez, 1988), as well as Perez's technological style (Perez, 1983), later captured in the term “technological paradigm" and finally “technological revolution" (Perez, 2002). Perez’s concept assumes the need for a clash between an old and a new system to bring forward a new technological style, as well as political and social realignments (see also Spruyt, 1994). This concept invokes the idea of a "punctuated equilibrium" of evolutionary development (Eldredge, 1985; Somit \& Peterson, 1992), mainly associated with the work of Stephen J. Gould (2002). 
Challenging the common interpretations of Darwin's view of evolution as a linear and progressive process, and arguing against the view of evolution as a "ladder" or a "cone," Gould argues that evolution simply "is adaptation to changing environments, not progress" (Gould, 1989, p. 32). Rather than gradually emerging, change can be dramatic and sudden, taking the form of punctuated equilibrium. Stages of relatively slow movement and little change are interrupted by sudden and dramatic changes. Such broad exogenous change,i.e. punctuation, will lead to a spur in radically new forms, essentially the clustering of innovations demonstrated by Schumpeter and the neo-Schumpeterian school.

\section{Social Structures of Accumulation (SSA) and French Regulationist Schools}

Rooted in the neo-Marxist tradition, the Social Structures of Accumulation (SSA) school defines capitalism as a wage-labor system of commodity production for profit. In order to overcome purely Marxist analysis, the SSA school proposes an intermediate or mezzo-level of analysis between the capitalist system and the individual worker. SSA is historically based, and focuses

on the logic of long swings and stages of capitalism. In this view, macrodynamic analysis should begin with the (external) political-economic environment affecting individual capitalists' possibilities for capital accumulation, consisting of all the institutions that impinge upon the accumulation process, and referred to by SSA scholars as the social structure of accumulation (Kotz, McDonough, \& Reich, 1994). The SSA school identifies five principal tendencies dominating the trajectory of capitalist development (Kotz et al., 1994, pp. 11-12):

(1) capitalist accumulation continually attempts to expand the boundaries of the capitalist system; 
(2) capitalist accumulation persistently increases the size of large corporations and concentrates the control and ownership of capital in proportionately fewer hands;

(3) the accumulation of capital spreads wage labor as the prevalent system of production, draws an increasing proportion of the population into wage-labor status, and replenishes the reserve pool of labor;

(4) capitalist accumulation continually changes the labor process, both through employers' introduction of improved technologies and new machines, and through the imposition of increasingly intensive labor-management systems upon workers; and

(5) in order to defend themselves against the effects of capitalist accumulation, workers have responded with their own activities and struggles.

Likewise rooted in the neo-Marxist tradition, the French Regulation school argues that the combination of institutional forms, the wage relation, the dynamics of relations among social groups and classes, regimes of accumulation, and modes of regulation, define the mode of development. Theories of regulation make growth and crisis, along with their spatial and temporal variability, the central questions of economic analysis and connect these phenomena with the prevailing forms of social organization (Boyer, 1990). What unites the SSA and Regulationist schools is a concern for precise definitions, a study of the nature of the change, and the evolution of those sequences. Both schools are reluctant to accept any cycles or waves underlying these sequences, though they share many common features with long-wave analysis. However, the heavy emphasis both (neo-Marxist) schools make on the selection of marketarrangements and institutions, mainly through the focus on the social relationship structure of the capitalist system, have left them open to considerable criticism. While an important sub-system, 
social relational structures are not the only selection mechanisms affecting the evolution of the world system as argued above by the approaches rooted in the neo-Schumpeterian tradition.

\section{Critique of Evolutionary Approaches}

Evolutionary approaches, especially as applied outside of biology and adapted for the social realm of human societies and development, are not without critics. This criticism centers mostly on two points: an inherent bias and over emphasis on traits resulting in "genetic determinism," and an argument for human distinctiveness as a result of a broader range of options resulting from our ability to learn and reflect critically on their own behavior.

\section{Genetic Determinism}

A general view often encountered in critiques of structuralist approaches is the accusation that the structures directly determine outcomes. This criticism has been voiced persistently in the case of evolutionary systems theory, ever since Darwin proposed his concepts. This argument was put forward for example by Lewontin et al. (1984), accusing advocates of evolutionary systems theory in the social sciences of scientifically unsubstantiated biological determinism, describing the logic thus:

Human lives and actions are inevitable consequences of the biochemical properties of the cells that make up the individual [in shaping human characteristics that are] uniquely determined by the constituents of the genes possessed by each individual. Ultimately, all human behavior — hence all human society — is governed by a chain of determinants 
that runs from the gene to the individual to the sum of the behaviors of all individuals. (Lewontin et al., 1984, p. 6)

The earlier discussion of evolutionary theory should make it clear that this description of the role of genes in the evolutionary process is at best a crude misconstruction of the actual causal linkages between the genotype and phenotype, as well as selection mechanisms found in both natural and social evolutionary models, even in the biobehavioral school. Modern evolutionary theory simply does not allow for a simple genetic causal predetermined outcome (Forber, 2009). Far from arguing for a predetermined outcome either by structure or genetic predisposition, genetic compositions and structural constraints are merely generating impulses and possibilities that given a set of conditions may (or may not) lead to. This is true for social as well as natural evolutionary systemic arguments.

Harvey (1982), for example, uses the analogy to a living organism to make this point. Whereas DNA can trigger the development of the needed organs for growth, it cannot assure that all the conditions of growth will be in place: for example, malnutrition can stunt the brain, iodine deficiency can cause the thyroid to fail, etc. Similarly, capitalist relations of production are a generative structure that may, for example, stimulate credit mechanisms that allow for larger investments in production facilities, more extensive infrastructure, greater continuity in sales, which in turn have positive feedback-effects on capital accumulation. However, this credit system can malfunction, setting off financial crises that interfere with the production process. So, rather than arguing for a deterministic outcome through structure, evolutionary studies instead examine the evolutionary drive (Allen et al., 1992; Allen \& McGlade, 1987) that creates a possibility space (Clark et al., 1995), or the range of potential options for change open to the system and its parts. 


\section{Human Distinctiveness}

Giddens' discussion may serve as an example of the 'human distinctiveness' line of criticism against evolutionary systems theory as applied to social and human history. Giddens argues that “human history does not have an evolutionary 'shape,' and positive harm can be done by attempting to compress it into one" (Giddens, 1984, p. 236), and lists three arguments about why that is the case:

1. "Human beings make their history in cognizance of that history, that is, as reflexive beings cognitively appropriating time rather than merely 'living' it. ... The nub of the matter, however, is that the reflexive nature of human social life subverts the explication of social change in terms of any simple and sovereign set of causal mechanisms. Getting to know what goes on 'in' history becomes not only an inherent part of what 'history' is but also a means of transforming 'history”' (p. 237).

2. "Evolutionary theory in biology depends upon postulates of the independence of the origin of species and unchangeability of species save through mutation. These conditions do not apply in human history. 'Societies' simply do not have the degree of 'closure' that species do. Biologists can fairly easily answer the question: what evolves? But there is no readily available 'unit of evolution' in the sphere of the social sciences" (p. 237).

3. "Human history is not ... a "world-growth story"” (p. 237). "The modern world is born out of discontinuity with what went before rather than continuity with it. It is the nature of this discontinuity — the specificity of the world ushered in by the advent of industrial 
capitalism, originally located and founded in the West - which it is the business of sociology to explain as best it can" (p. 239).

Readers by now will recognize that the problem lies not so much with evolutionary systems theory, but, again, rather more with Giddens' representation of it. He implies that evolutionary theories leave no room for learning — outside of genetic storage of information — or the role of

choice in the adaptation processes. These are widely held misconceptions of evolutionary theory. It also shows a fundamental lack of understanding of the role populations play in evolutionary theory. Learning is, indeed, an important element in evolutionary development (Plotkin, 2010).

\section{Conclusion}

The processes of interaction between individuals and groups, the environments they are embedded in both physically and socially and the impact these interactions have on all three in developmental terms is far more deeply theorized than Giddens or many of the critics of evolutionary approaches in the social sciences seem to be aware (Dunbar, 1998). The point of evolutionary explanations is not to make the case that humans are not capable of making choices, but rather that the capacity to make those choices derives from and depends on previous choices made; and that this process is also bound by our biological evolution and/or our cognitive limitations, regardless of the relative complexity of human learning capacity. Advances in our understanding of information and the formation of complexity and complex systems allows us to use the tools and insights of evolutionary biology, and other related sciences, without the need to 
reduce human interactions to pre-determined, genetically pre-programmed biological activity, rather than choices of self-aware actors.

Evolutionary approaches have a long-standing tradition outside of the political science literature. They have been firmly integrated into many different literatures in the social sciences and related fields with a growing awareness of the need to apply interdisciplinary and multi-methodological approaches. This is especially true in the study of the large complex system more commonly known as globalization, or in the terminology of the literature presented here, world(-)system development.

\section{References}

Allen, P. M., Clark, N., \& Perez-Trejo, F. (1992). Strategic planning of complex economic systems. Review of Political Economy, 4(3), 275-290.

https://doi.org/10.1080/09538259200000020

Allen, P. M., \& McGlade, J. M. (1987). Evolutionary drive: The effect of microscopic diversity, error making and noise. Foundations of Physics, 17(7), 723-728.

https://doi.org/10.1007/BF01889545

Andersen, E. S. (1994). Evolutionary economics: Post contributions. London: Pinter.

Aunger, R. (2007). Major transitions in "big" history. Technological Forecasting and Social Change, 74(8), 1137-1163. https://doi.org/10.1016/j.techfore.2007.01.006 
Axelrod, R. M. (Ed.). (1976). Structure of decision: The cognitive maps of political elites.

Princeton, NJ: Princeton University Press.

Axelrod, R. M. (1984). The evolution of cooperation. New York: Basic.

Axelrod, R. M. (1997). The complexity of cooperation: Agent-based models of competition and collaboration. Princeton, NJ: Princeton University Press.

Baum, J. A. C., \& Oliver, C. (1996). Toward an institutional ecology of organizational founding. Academy of Management Journal, 39(5), 1378-1428. https://doi.org/10.2307/257003

Beinhocker, E. D. (2006). Origin of wealth: Evolution, complexity, and the radical remaking of economics. Cambridge, MA: Harvard Business School Press.

Berry, B. J. L. (1991). Long-wave rhythms in economic development and political behavior. Baltimore, PA: Johns Hopkins University Press.

Bowler, P. J. (2003). Evolution: The history of an idea (3rd completely rev. and expanded ed.). Berkeley: University of California Press.

Bowles, S., \& Gintis, H. (2013). A cooperative species: Human reciprocity and its evolution. Princeton, NJ: Princeton University Press.

Boyd, R., \& Richerson, P. J. (1985). Culture and the evolutionary process. Chicago: University of Chicago Press.

Boyer, R. (1990). The Regulation school: A critical introduction. (C. Charney, Trans.). New York: Columbia University Press. 
Campbell, D. T. (1974a). Downward causation in hierarchically organised biological systems. In F. J. Ayala \& T. G. Dobzhansky (Eds.), Studies in the philosophy of biology: Reduction and related problems (pp. 179-186). London: Macmillan Education.

Campbell, D. T. (1974b). Evolutionary Epistemology. In P. A. Schilpp (Ed.), The Philosophy of Karl Popper (Vol. 1, pp. 412-463). La Salle, IL: Open Court.

Campbell, D. T., Brewer, M. B., \& Collins, B. E. (Eds.). (1981). Scientific Inquiry and the Social Sciences. San Francisco: Jossey-Bass.

Chase-Dunn, C. K., \& Hall, T. D. (1997). Rise and demise: Comparing world-systems. Boulder, CO: Westview.

Christian, D. (2011). Maps of time: An introduction to big history; with a new preface [to the 2011 edition]. Berkeley: University of California Press.

Clark, N., Perez-Trejo, F., \& Allen, P. M. (1995). Evolutionary dynamics and sustainable development: A systems approach. Aldershot, UK: Edward Elgar.

Cronk, L., \& Leech, B. L. (2013). Meeting at Grand Central: Understanding the social and evolutionary roots of cooperation. Princeton, N.J.: Princeton University Press.

Csányi, V. (1989). Evolutionary systems and society: A general theory of life, mind, and culture. Durham, NC: Duke University Press.

Dark, K. R. (1998). The waves of time: Long-term change and international relations. London: Pinter. 
Darwin, C. (1872). On the origin of species by means of natural selection: Or, the preservation of favored races in the struggle for life (5th ed., with additions and corrections). New York: D. Appleton.

Dawkins, R. (1982). Replicators and vehicles. In King's College Sociobiology Group (Ed.), Current problems in sociobiology (pp. 45-64). Cambridge: Cambridge University Press.

Denemark, R. A., Friedman, J., Gills, B. K., \& Modelski, G. (Eds.). (2000). World system history: The social science of long-term change. New York: Routledge.

Devezas, T. C. (2005). Evolutionary theory of technological change: State-of-the-art and new approaches. Technological Forecasting and Social Change, 72(9), 1137-1152.

https://doi.org/10.1016/j.techfore.2004.10.006

Devezas, T. C., \& Corredine, J. T. (2001). The biological determinants of long-wave behavior in socioeconomic growth and development. Technological Forecasting \& Social Change, 68(1), 157.

Devezas, T. C., \& Corredine, J. T. (2002). The nonlinear dynamics of technoeconomic systems: An informational interpretation. Technological Forecasting and Social Change, 69(4), 317-357. https://doi.org/10.1016/S0040-1625(01)00155-X

Devezas, T. C., \& Modelski, G. (2003). Power law behavior and world system evolution: A millennial learning process. Technological Forecasting \& Social Change, 70(9), 819-859. https://doi.org/10.1016/S0040-1625(03)00011-8

Diehl, P. F., \& Goertz, G. (2000). War and peace in international rivalry. Ann Arbor: The University of Michigan Press. 
Dopfer, K. (Ed.). (2005a). Economics, evolution and the state: The governance of complexity. Cheltenham, UK: Edward Elgar.

Dopfer, K. (Ed.). (2005b). The evolutionary foundations of economics. New York: Cambridge University Press.

Dopfer, K. (Ed.). (2012). Evolutionary economics: Program and scope. Dordrecht: Springer Netherlands.

Dosi, G. (1984). Technical change and industrial transformation: The theory and an application to the semiconductor industry. London: Macmillan. https://doi.org/10.1007/978-1-349-17521-5

Dosi, G., Freeman, C., Nelson, R. R., Silverberg, G., \& Soete, L. L. G. (Eds.). (1988). Technical change and economic theory. London: Pinter.

Duijn, J. J. van. (1983). The long wave in economic life. London: Allen \& Unwin.

Dunbar, R. I. M. (1998). The social brain hypothesis. Evolutionary Anthropology: Issues, News, and Reviews, 6(5), 178-190.

Durham, W. H. (1991). Coevolution: Genes, culture, and human diversity. Stanford, CA: Stanford University Press.

Eldredge, N. (1985). Time frames: The rethinking of Darwinian evolution and the theory of punctuated equilibria. New York: Simon \& Schuster.

Eldredge, N., \& Gould, S. J. (1972). Punctuated equilibria: An alternative to phyletic gradualism. In T. J. M. Schopf (Ed.), Models in Paleobiology (pp. 82-115). San Francisco: Freeman Cooper. 
Falger, V. S. E. (1994). Human nature in modern international relations: Theoretical backgrounds. Research in Biopolitics, 5, 155-175.

Farkas, A. (1996). Evolutionary Models in Foreign Policy Analysis. International Studies Quarterly, 40(3), 343-361.

Florini, A. (1996). The evolution of international norms. International Studies Quarterly, 40(3), 363-389. https://doi.org/10.2307/2600716

Forber, P. (2009). Introduction: A primer on adaptationism. Biology and Philosophy, 24(2), 155159.

Fornahl, D., Henn, S., \& Menzel, M.-P. (Eds.). (2010). Emerging clusters: Theoretical, empirical and political perspectives on the initial stage of cluster evolution. Cheltenham, UK: Edward Elgar.

Frank, A. G., \& Gills, B. K. (Eds.). (1993). The world system: Five hundred years or five thousand? London: Routledge.

Freeman, C., \& Louçã, F. (2001). As time goes by: From the industrial revolutions to the information revolution. Oxford, UK: Oxford University Press.

Freeman, C., \& Perez, C. (1988). Structural Crises of Adjustment: Business Cycles and Investment Behaviour. In G. Dosi, C. Freeman, R. R. Nelson, G. Silverberg, \& L. L. G. Soete (Eds.), Technical change and economic theory. London: Pinter.

Giddens, A. (1984). The constitution of society: Outline of the theory of structuration. Berkeley, CA: University of California Press. 
Gilpin, R. (1996). Economic evolution of national systems. International Studies Quarterly, 40(3), 411-431. https://doi.org/10.2307/2600718

Gintis, H., Doebeli, M., \& Flack, J. (2012). The evolution of human cooperation. Cliodynamics: The Journal of Theoretical and Mathematical History, 3(1), 172-190.

Goldstein, J. S. (1988). Long cycles: Prosperity and war in the modern age. New Haven, CT: Yale University Press.

Gould, S. J. (1981). The mismeasure of man. New York: Norton.

Gould, S. J. (1989). Wonderful life: The burgess shale and the nature of history. New York: W. W. Norton.

Gould, S. J. (2002). The structure of evolutionary theory. Cambridge, MA: Belknap Press of Harvard University Press.

Hall, P. G., \& Preston, P. (1988). The carrier wave: New information technology and the geography of innovation, 1846-2003. London: Unwin Hyman.

Hall, R. B. (1999). National collective identity: Social constructs and international systems. New York: Columbia University Press.

Hall, T. D. (Ed.). (2017). Comparing globalizations: Historical and world-system approaches. New York: Springer.

Harrison, N. E. (Ed.). (2006). Complexity in world politics: Concepts and methods of a new paradigm. Albany: SUNY Press.

Harvey, D. (1982). The limits to capital. Oxford: Blackwell. 
Hidalgo, C. A. (2015). Why information grows: The evolution of order, from atoms to economies. New York: Basic Books.

Hodgson, G. M. (1993). Economics and evolution: Bringing life back into economics. Ann Arbor: University of Michigan Press.

Hodgson, G. M. (1996). An evolutionary theory of long-term economic growth. International Studies Quarterly, 40(3), 391-410.

Hodgson, G. M. (2004). The evolution of institutional economics: Agency, structure, and Darwinism in American institutionalism. New York: Routledge.

Hodgson, G. M., \& Knudsen, T. (2007). Information, complexity and generative replication. Biology \& Philosophy, 23(1), 47-65. https://doi.org/10.1007/s10539-007-9073-y

Hopkins, T. K., \& Wallerstein, I. M. (1980). Processes of the world-system. Beverly Hills, CA: Sage.

Hull, D. L. (1988). Science as a process: An evolutionary account of the social and conceptual development of science. Chicago: University of Chicago Press.

Huntington, S. P., Ajami, F., Mahbubani, K., Bartley, R. L., Binyan, L., Kirkpatrick, J. J., ... Brezinnski, Z. (2013). The Clash of Civilizations? The Debate: 20th Anniversary Edition. (G. Rose, Ed.). New York: Foreign Affairs.

Jervis, R. (1997). System effects: Complexity in political and social life. Princeton, NJ: Princeton University Press. 
Johnson, G. R. (2011). Politics and the life sciences: An unfinished revolution. Politics and the Life Sciences, 30(2), 43-64. https://doi.org/10.2990/30_2_43

Jones, E. L. (2000). Growth recurring: Economic change in world history. Ann Arbor: University of Michigan Press. https://doi.org/10.3998/mpub.11659 (Original work published 1988)

Kahler, M. (1999). Evolution, choice, and international change. In D. A. Lake \& R. Powell (Eds.), Strategic choice and international relations (pp. 165-196). Princeton, NJ: Princeton University Press.

Kleinknecht, A., Mandel, E., \& Wallerstein, I. M. (Eds.). (1992). New findings in long-wave research. New York: St. Martin’s Press.

Klüver, J. (2000). The dynamics and evolution of social systems: New foundations of a mathematical sociology. Boston: Kluwer.

Kondratieff, N. D., \& Stolper, W. F. (1935). The long waves in economic life. The Review of Economics and Statistics, 17(6), 105. https://doi.org/10.2307/1928486

Kosse, K. (1994). The evolution of large, complex groups: A hypothesis. Journal of Anthropological Archaeology, 13(1), 35-50. https://doi.org/10.1006/jaar.1994.1003

Kotz, D. M., McDonough, T., \& Reich, M. (Eds.). (1994). Social structures of accumulation:

The political economy of growth and crisis. Cambridge: Cambridge University Press.

Kradin, N. N. (2015). Nomadic empires: origins, rise, decline. In N. N. Kradin, D. M.

Bondarenko, \& T. J. Barfield (Eds.), Nomadic pathways in social evolution (pp. 73-87). LacBeauport: Mea. 
Krasner, S. D. (1984). Approaches to the state: Alternative conceptions and historical dynamics. Comparative Politics, 16(2), 223-246.

Langer, J., \& Killen, M. (Eds.). (1998). Piaget, evolution, and development. Mahwah, NJ: L. Erlbaum.

Lewontin, R. C. (2003). Biology as ideology: The doctrine of DNA. Toronto: Anansi.

Lewontin, R. C., Rose, S., \& Kamin, L. J. (1984). Not in our genes: Biology, ideology and human nature. London: Pantheon.

Mainzer, K. (2007). Thinking in complexity: The computational dynamics of matter, mind, and mankind (5th rev. and enl. ed). Berlin: Springer.

Makasheva, N. A., Samuels, W. J., \& Barnett, V. (Eds.). (1998). The works of Nikolai D. Kondratiev (Vols. 1-4). London: Pickering \& Chatto.

Maschner, H. D. G. (Ed.). (1996). Darwinian archaeologies. New York: Plenum Press.

Mayr, E. (1982). The growth of biological thought: Diversity, evolution, and inheritance. Cambridge, MA: Harvard University Press.

Mayr, E. (2001). What evolution is. New York: Basic Books.

McNeill, J. R., \& McNeill, W. H. (2003). The Human Web: A Bird's-Eye View of World History. New York: W.W. Norton.

McNeill, W. H. (1982). The pursuit of power: Technology, armed force, and society since A.D. 1000. Chicago: University of Chicago Press. 
McNeill, W. H. (1991). The rise of the West: A history of the human community. Chicago:

University of Chicago Press.

McNeill, W. H. (1999). A world history. New York: Oxford University Press.

Miller, J. H., \& Page, S. E. (2007). Complex adaptive systems: An introduction to computational models of social life. Princeton, NJ: Princeton University Press.

Mitleton-Kelly, E. (Ed.). (2003). Complex systems and evolutionary perspectives on organisations: The application of complexity theory to organisations. Amsterdam: Pergamon.

Modelski, G. (1987). Long cycles in world politics. Seattle: University of Washington Press.

Modelski, G. (1990). Is world politics evolutionary learning? International Organization, 44(1), 1-24. https://doi.org/10.1017/S0020818300004628

Modelski, G. (1996). Evolutionary paradigm for global politics. International Studies Quarterly, 40(3), 321-342.

Modelski, G. (2000). World system evolution. In R. A. Denemark, J. Friedman, B. K. Gills, \& G. Modelski (Eds.), World system history: The social science of long-term change (pp. 24-53).

London: Routledge.

Modelski, G. (2001). Evolutionary World Politics: Problems of Scope and Method. In W. R. Thompson (Ed.), Evolutionary interpretations of world politics (pp. 16-29). New York:

Routledge.

Modelski, G., Devezas, T. C., \& Thompson, W. R. (Eds.). (2008). Globalization as evolutionary process: modeling global change. London: Routledge. 
Modelski, G., \& Poznanski, K. (1996). Evolutionary paradigms in the social sciences. International Studies Quarterly, 40(3), 315-320.

Modelski, G., \& Thompson, W. R. (1996). Leading sectors and world powers: The coevolution of global politics and economics. Columbia, SC: University of South Carolina Press.

Nelson, R. R., \& Winter, S. G. (1974). Neoclassical vs evolutionary theories of economic growth: Critique and and prospectus. Economic Journal, 84(336), 886-905.

Nelson, R. R., \& Winter, S. G. (1982). An evolutionary theory of economic change. Cambridge: Belknap Press of Harvard University Press.

Nelson, R. R., \& Winter, S. G. (2002). Evolutionary theorizing in economics. Journal of Economic Perspectives, 16(2), 23-46. https://doi.org/10.1257/0895330027247

Niedenzu, H.-J., Meleghy, T., \& Meyer, P. (Eds.). (2015). New evolutionary social science: Human nature, social behavior, and social change. London: Routledge.

North, D. C. (1981). Structure and change in economic history. New York: Norton.

Nowak, M. A. (2006). Evolutionary dynamics: Exploring the equations of life. Cambridge, MA: Belknap Press of Harvard University Press.

Nowak, M. A., \& Coakley, S. (Eds.). (2013). Evolution, games, and God: The principle of cooperation. Cambridge, MA: Harvard University Press.

O’Brien, M. J. (1996). Evolutionary archaeology: Theory and application. Salt Lake City: University of Utah Press. 
O’Brien, M. J., \& Lyman, R. L. (2000). Applying evolutionary archaeology: A systematic approach. New York: Kluwer Academic/Plenum.

Perez, C. (1983). Structural change and assimilation of new technology in the economic and social systems. Futures, 15(5), 357-375.

Perez, C. (2002). Technological revolutions and financial capital: The dynamics of bubbles and golden ages. Cheltenham, UK: Edward Elgar.

Plotkin, H. C. (Ed.). (1988). The role of behavior in evolution. Cambridge, MA: MIT Press.

Plotkin, H. C. (1994). The nature of knowledge: Concerning adaptations, instinct and the evolution of intelligence. London: Allen Lane.

Plotkin, H. C. (2010). Evolutionary worlds without end. Oxford: Oxford University Press.

Polanyi, K. (1944). The great transformation. New York: Farrar \& Rinehart.

Polanyi, K., Arensberg, C. M., \& Pearson, H. W. (Eds.). (1957). Trade and market in the early empires: Economies in history and theory. Glencoe, IL: Free Press.

Pomeranz, K. (2000). The great divergence: China, Europe, and the making of the modern world economy. Princeton, NJ: Princeton University Press.

Pomper, P., Elphick, R., \& Vann, R. T. (1995). World historians and their critics. Middletown, CT: Wesleyan University.

Pomper, P., Elphick, R., \& Vann, R. T. (Eds.). (1998). World history: Ideologies, structures, and identities. Malden, MA: Blackwell. 
Reijnders, J. (Ed.). (1997). Economics and evolution. Cheltenham, UK: Edward Elgar.

Rennstich, J. K. (2007). Is Globalization Self-Organizing? In G. Modelski, T. Devezas, \& W. R. Thompson (Eds.), Globalization as Evolutionary Process: Modeling, Simulating, and Forecasting Global Change (pp. 88-108). London: Routledge.

Rennstich, J. K. (2008). The making of a digital world: The evolution of technological change and how it shaped our world. New York: Palgrave Macmillan.

Reynolds, V., Falger, V. E., \& Vine, I. (Eds.). (1986). The sociobiology of ethnocentrism: Evolutionary dimensions of xenophobia, discrimination, racism, and nationalism. Athens: University of Georgia Press.

Rostow, W. W. (1952). The process of economic growth. New York: Norton.

Runciman, W. G. (1983). A treatise on social theory: The methodology of social theory (Vol. 1). Cambridge: Cambridge University Press.

Sanderson, S. K. (1990). Social evolutionism: A critical history. Cambridge, MA: Blackwell.

Sanderson, S. K. (2001). The evolution of human sociality: A Darwinian conflict perspective. Lanham, MD: Rowman \& Littlefield.

Sassen, S. (2006). Territory, authority, rights: From medieval to global assemblages. Princeton, NJ: Princeton University Press.

Saviotti, P., \& Metcalfe, J. S. (Eds.). (1991). Evolutionary theories of economic and technological change: Present status and future prospects. Philadelphia: Harwood Academic. 
Sawyer, R. K. (2005). Social emergence: Societies as complex systems. Cambridge, UK: Cambridge University Press.

Schumpeter, J. A. (1912). Theorie der wirtschaftlichen Entwicklung. Leipzig: Duncker \& Humblot.

Schumpeter, J. A. (1996). History of economic analysis. (E. B. Schumpeter, Ed.). New York: Oxford University Press. (Original work published 1954)

Shannon, T. R. (1989). An introduction to the world-system perspective (2nd ed.). Boulder, CO: Westview.

Shaw, M. (2000). Theory of the global state: Globality as an unfinished revolution. New York: Cambridge University Press.

Somit, A., \& Peterson, S. A. (Eds.). (1992). The dynamics of evolution: The punctuated equilibrium debate in the natural and social sciences. Ithaca, NY: Cornell University Press.

Somit, A., \& Peterson, S. A. (2003). Human evolution and public policy: An evolutionary approach. Basingstoke, UK: Palgrave Macmillan.

Spier, F. (2010). Big history and the future of humanity. Chichester, UK: Wiley-Blackwell.

Spruyt, H. (1994). The sovereign state and its competitors: An analysis of systems change. Princeton, NJ: Princeton University Press.

Teisman, G., Buuren, A. van, \& Gerrits, L. M. (Eds.). (2009). Managing complex governance systems: Dynamics, self-organization and coevolution in public investments. New York: Routledge. 
Teltser, P. A. (1995). Evolutionary archaeology: Methodological issues. Tucson: University of Arizona Press.

Thayer, B. A. (2004). Darwin and international relations: On the evolutionary origins of war and ethnic conflict. Lexington: University Press of Kentucky.

Thompson, W. R. (Ed.). (1983). Contending approaches to world system analysis. Beverly Hills, CA: Sage.

Thompson, W. R. (Ed.). (2001). Evolutionary Interpretations of World Politics. New York: Routledge.

Toynbee, A. J. (1934). A study of history. London: Oxford University Press.

Turchin, P. (2016). Ultrasociety: how 10.000 years of war made humans the greatest cooperators on earth. Chaplin, CT: Beresta.

Vasko, T. (Ed.). (1987). The long-wave debate: Selected papers from an IIASA (International Institute for Applied Systems Analysis) International Meeting on Long-Term Fluctuations in Economic Growth: Their Causes and Consequences, Held in Weimar, GDR, June 1014, 1985. Berlin: Springer.

Wallerstein, I. M. (1974). The modern world-system: Capitalist agriculture and the origins of the European world-economy in the sixteenth century (Vol. 1). New York: Academic Press.

Wallerstein, I. M. (1993). World system versus world-systems: A critique. In A. G. Frank \& B. K. Gills (Eds.), The world system: Five hundred years or five thousand? (pp. 292-297). London: Routledge. 
Wallerstein, I. M. (1995). The modern world-system and evolution. Journal of World-Systems

Research, 1(19), 1-15. https://doi.org/10.5195/jwsr.1995.46

Wallerstein, I. M. (2004). World-systems analysis: An introduction. Durham: Duke University Press.

White, L. A. (1959). The evolution of culture: The development of civilization to the fall of Rome. New York: McGraw-Hill.

Wilson, D. S., \& Sober, E. (1994). Reintroducing group selection to the human behavioral sciences. Behavioral and Brain Sciences, 17(4), 585-654.

https://doi.org/10.1017/S0140525X00036104

Wilson, E. O. (1975). Sociobiology: The new synthesis. Cambridge, MA: Belknap Press of Harvard University Press.

Wilson, E. O. (1978). On human nature. Cambridge, MA: Harvard University Press.

Witt, U. (1991). Reflections on the present state of evolutionary economic theory. In G. M. Hodgson \& E. Screpanti (Eds.), Rethinking economics: Markets, technology, and economic evolution (pp. 289-311). Aldershot, UK: Edward Elgar.

Wright, A. (2007). Glut: Mastering information through the ages. Washington, DC: Joseph Henry Press.

Ziman, J. M. (Ed.). (2000). Technological innovation as an evolutionary process. Cambridge: Cambridge University Press. 


\section{Buddenbrook Cycle}

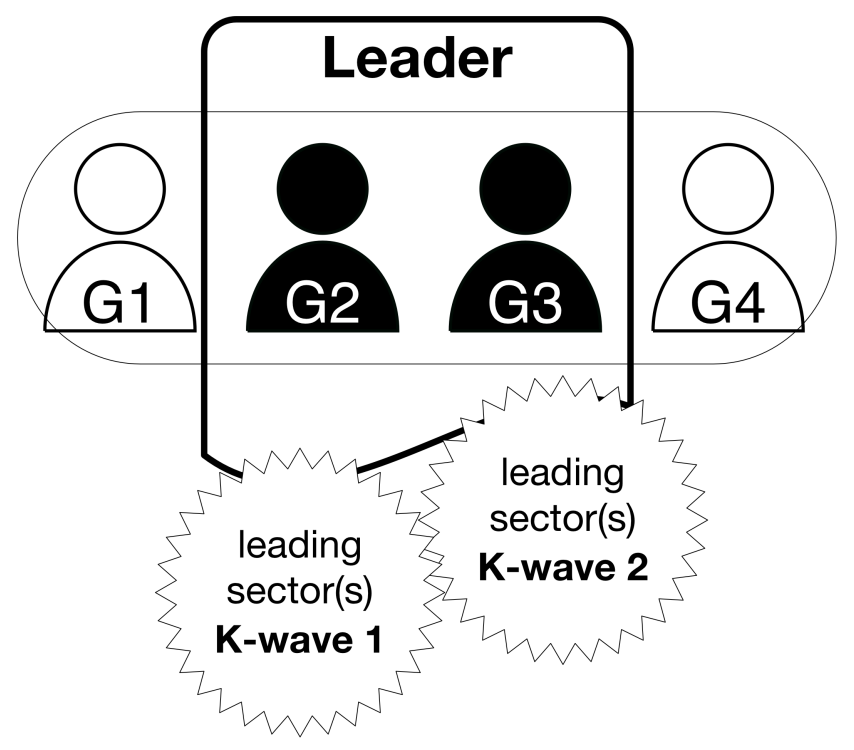

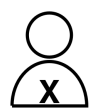

Pre/Post K-wave

Generation

Founder and tail generation 25-30 yrs

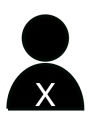

K-wave Generation Leading sector generation 25-30 yrs

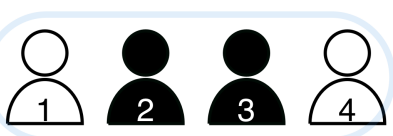

Generational Buddenbrook cycle Four consecutive generations 100-120 yrs

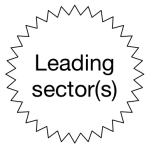

K-waves leadingsector based 25-30 yrs

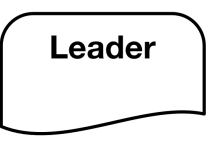

Long cycles of systemic leadership 100-120 yrs

Figure 1: The Buddenbrook Cycle - Schematic description of inter-generational learning, innovation/mutation, and adaption as part of a K-wave process evolutionary learning cycle (adapted from Rennstich, 2007, p. 99) 